\title{
Military Bands and Government Documents
}

\author{
Daniel E. Ray
}

$S_{\text {ines }}$

ince before the founding of the United States, musicians have been an integral part of the military. Throughout history armies have used trumpets and drums to enhance communication and assist the movement of mass forces. ${ }^{1}$ Over time, the military has influenced both the makeup of musical ensembles, and styles of popular music. The modern American wind band featuring brass, woodwinds and percussion, is modeled after British military bands. ${ }^{2}$ And the marches of John Phillip Sousa, who served as the director of the President's Own Marine Band for twelve years, ${ }^{3}$ remain popular to this day. His "Stars and Stripes Forever" is considered our national march. Today, the US Army declares itself "the oldest and largest employer of musicians in the world." Military musicians around the world perform in bands, choruses, orchestras and popular ensembles. Such a rich historical and cultural resource is well documented in government publications. It is possible that official information could be utilized by service members, policy makers and the general public. The scope of this paper is to discuss types of information sources, highlighting examples relating to the current state of military bands.

\section{Background}

The tradition of bands in the United States military dates back to colonial times.' From the fife and drums of Washington's Continental Army to the regimental bands of the Civil War to the rock bands entertaining troops in Iraq, military musicians have provided music that inspires and entertains soldier and civilian alike. The official mission of US Army Bands is to "provide music throughout the spectrum of military operations, instill in our soldiers the will to fight and win, foster the support of our citizens, and promote our national interests at home and abroad." ${ }^{6}$ Although each of the armed services explains it slightly differently, the ceremonial, inspirational and diplomatic roles of military musicians are demonstrated by soldiers, sailors, airmen, marines and coast guardsmen serving their country as musicians in bands throughout the United States and around the world. The role of military musicians was lauded by President Bill Clinton in a speech delivered at the White House on the two-hundredth anniversary of the founding of the President's Own Marine Corps Band. ${ }^{7}$ It was even the subject of an entire issue of Music Educators Journal, a publication of the National Association for Music Education. ${ }^{8}$ With more than six thousand musicians performing throughout the world in active duty, reserve and National Guard bands, ${ }^{9}$ the US military continues to support the contribution of military musicians. There are currently more than one hundred bands in the US Army, seventeen in the Air Force, thirteen in the Navy, twelve in the Marine Corps, and one in the Coast Guard. ${ }^{10}$

\section{Funding Legislation}

In 2012, the amount military musicians and the question of funding was the spotlight of an amendment to a defense spending bill in the US House of Representatives. ${ }^{11}$ Representative Betty McCollum sponsored a measure to limit spending on military bands from $\$ 325$ million to $\$ 200$ million. ${ }^{12}$ In a statement on her official website, the representative argued that the amount currently spent on military bands is neither strategically necessary nor fiscally responsible. "It is excessive and a luxury the Pentagon and taxpayers can no longer afford."13 This amendment was countered by Representative John Carter, who argued in favor of the important role military bands play in military ceremonies, funerals and patriotic celebrations. ${ }^{14}$ Ultimately, the measure was not included in the final bill. But the threat of spending cuts to military musical units continues. It was highlighted again by recent House legislation requesting a Government Accountability Office (GAO) report on the current state of military bands. The report requires GAO to "submit a report to the Senate Committee on Armed Services and the House Committee on Armed Services by February 1, 2017, 
on the Department of Defense requirement for military bands." ${ }^{15}$

GAO has previously prepared reports on military bands for Congress. Its report to the Senate Committee on Foreign Relations titled Expenditures for Public Affairs Activities, Department of Defense, dated July 1973, provided statistics on the five military bands located in the Washington, DC, area and three other bands on separate bases. ${ }^{16}$ A later GAO report on military bands was conducted in 1981. According to the report, there had been steady reductions in the number of bands and personnel since 1964. Despite a decrease in funding, however, the report noted an increase in the number of performances per band. ${ }^{17}$ The 2016 House report on military bands, in addition to the GAO report, requests from the Secretary of Defense a briefing on the current state of military bands and a recounting of spending reductions over the last five years. Band related items are also occasionally included in spending bills. For example, a Navy Fleet Band National Tour was listed in section 4301 of the House's military appropriations bill for fiscal year 2016. ${ }^{18}$

\section{Other Legislation}

Although spending bills feature prominently among legislative documents relating to military bands, there have been other actions that have affected musical units of the US military. One significant change in US military band policy has been to allow bands to make and sell recordings. Previously to 1974 this was not allowed as a protection to professional civilian musicians and the initial changes were limited in scope. In 1974 , House Resolution 14401 was passed, allowing military bands to make recordings in celebration of the Bicentennial celebration and Public Law No. 93-571 allowed the commercial sales of records from 1975 to 1976. Later, The National Defense Authorization Act for Fiscal Year 1991 allowed special bands to sell recordings. ${ }^{19}$

Finally, all military bands were allowed to distribute recordings as part of the National Defense Authorization Act for Fiscal Year 2010. ${ }^{20}$ The current law regarding recordings of

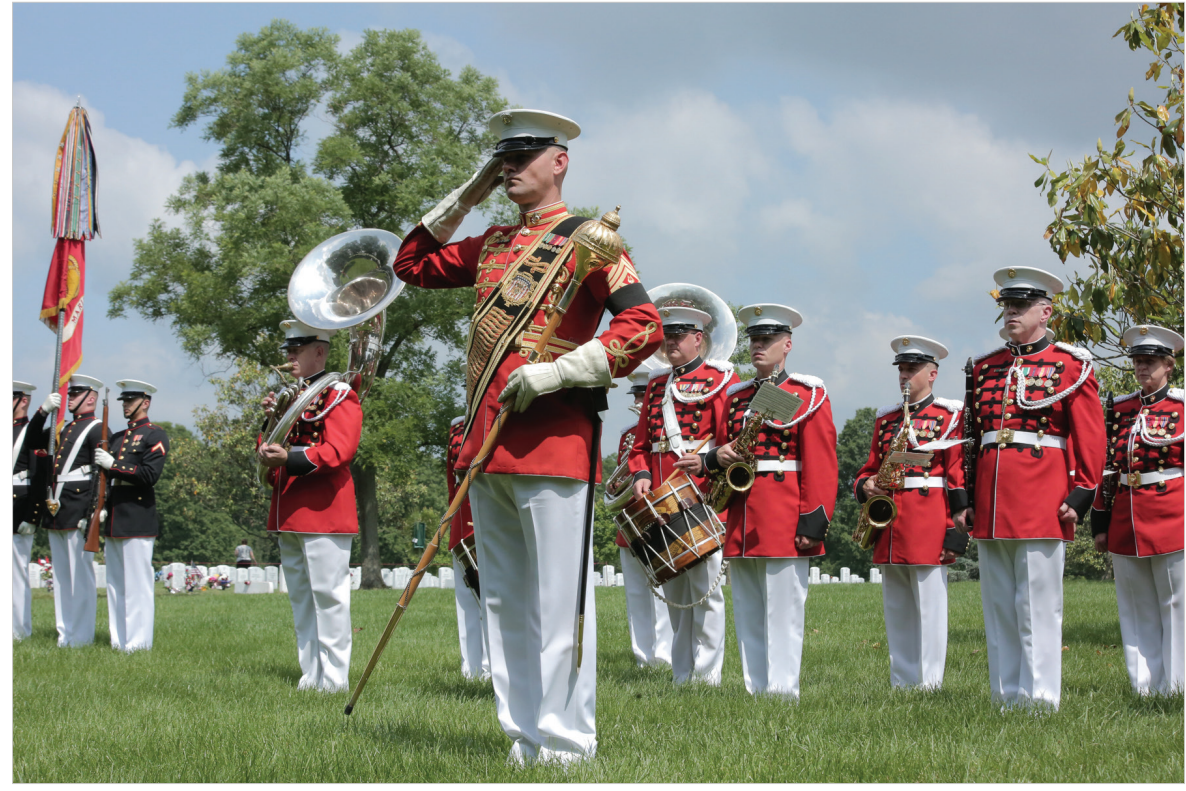

Figure 1. The Presidents Own Marine Corps Band performs funeral honors at Arlington National Cemetery, 2016. Source: "The President's Own," United States Marine Corps Band, www.marine band.marines.mil/Photos.aspx?igphoto $=2001546967$.

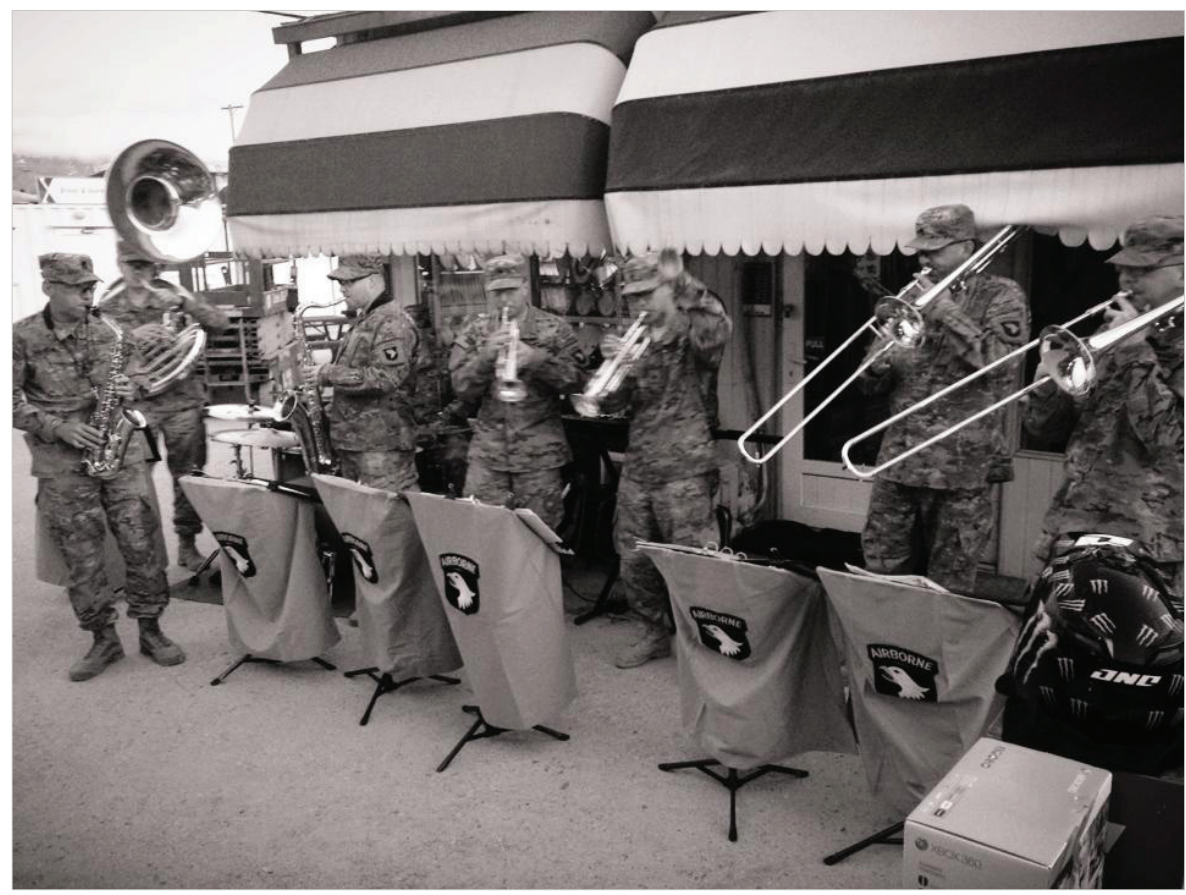

Figure 2. Members 101st Airborne Division Band perform for soldiers in Afghanistan. Source: Featured Photos, www.music.army.mil/images/slideshow/h_101ABN_2013_01.jpg. military bands states that, "A military musical unit may produce recordings for distribution to the public, at a cost not to exceed expenses of production and distribution." 21 This change in policy is reflected by the online music source, iTunes. A search for "us military band" returns recordings by the US Army Band, the US Military Academy Band, The United States Marine band and the US Air Force Band (figure 3). 
Showing results for "us military band"

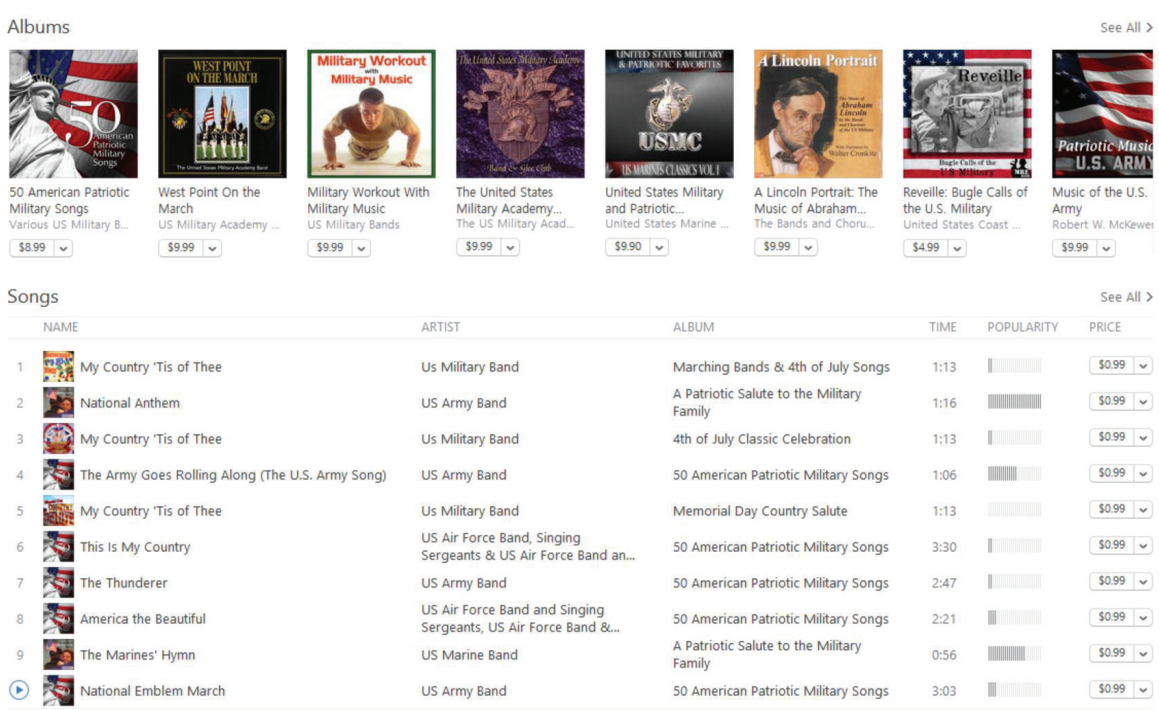

Figure 3. Search results for "us military band" in iTunes. Source: Image capture of iTunes taken by author.

\section{Executive Policy}

Department of Defense (DoD) policies also influence military bands. In 2005, the Base Realignment and Closure (BRAC) commission made significant changes to military bases, prompting many units to deactivate or relocate. Although the initial report did not mention Army Bands, The Army overview for fiscal year 2008/2009 listed changes to specific facilities affecting the bands at Fort Carson and Fort Eustis, as well as the Army Material Command Band and 151 Army Band. ${ }^{22}$ For some bands it meant being located to a new or renovated facility. In the case of the 70th Army Band, the closure of Fort Lawton actually resulted in deactivation of the band.

\section{Official Publications}

Government published documents related to military bands take a variety of forms, from official regulations and training manuals to legislative reports and public laws. An information need for military musicians is locating current versions of official publications. Each branch of the armed services manages its own publications. Regulations, Technical Manuals, Field Manuals and other official publications for the US Army are managed by the Army Publishing Directorate (APD) (armypubs.army.mil), which is currently undergoing a migration to a new website (www.apd.army.mil). Searching the open web for a document often results in an obsolete version from an unofficial source. Finding current documents often requires a knowledge of the document name, and specific agency producing it.

Many military bands also have their own websites, providing information regarding performances, educational resources, career opportunities and links to social media. In addition to printed and electronic visual media, military bands have released a variety of audio and video recordings available through their unit websites, YouTube channels and online music distributors such as iTunes. For members of military musical units, information and news about military bands is often found on social media, and through media outlets such as the Washington Post and Army Times. ${ }^{23}$ Archival documents are also available, including obsolete forms (figure 4) and historic photographs (figure 5).

\section{Dissemination of Information/ Access Issues}

Finding information about military bands has some built in obstacles. The first of which is the fact that many documents are produced and managed by each individual branch of service. As a result, searching for "military bands" may not include resources prepared by or for the individual services. A Google search for "us military band" returned more than 6 million results. The first page of results included six links for Army Band websites, a Marine Corps Band, a YouTube video featuring military musicians in concert, a tourist guide to Washington, DC and a Wikipedia entry for "United States military bands." The previously mentioned National Defense Authorization Act for Fiscal Year 1991, ${ }^{24}$ for example, affects all military bands, but is applied to each branch in Title 10 US Code in separate chapters for Army, Navy and Marine Corps and Air Force, with the exception of the Coast Guard, which is listed in its own Title of US Code. ${ }^{25}$ Recent legislation has further complicated search efforts by replacing the term "military band" with the term "military musical unit" in the US Code. ${ }^{26}$ Awareness of the switch in terminology is helpful in framing queries.

\section{Conclusion}

Performing musical units have been firmly established as an important part of the US military, and government published documents provide a rich resource for information about them. In addition to legislation and federal policy, the bands of each service create promotional materials, educational resources and recordings in a variety of media. As the GAO prepares its report on the current state of military musical units, it will be important for service members, policy makers and the general public to acquire current and historic information. There are voices on 

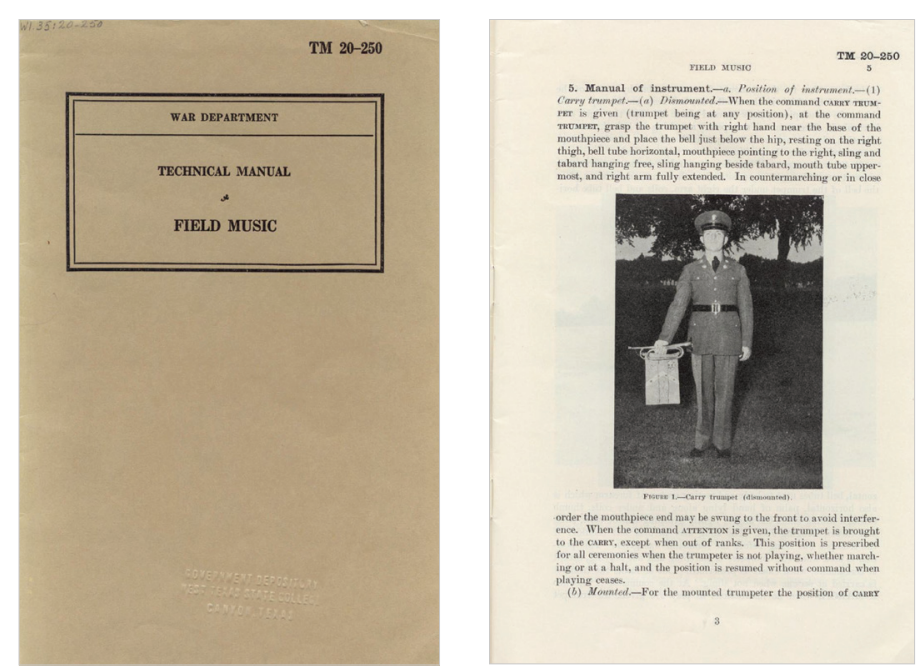

Figure 4. Technical Manual TM 20-250: Field Music, 1940. Source: Field Music [electronic resource]: technical manual. Online collection of Historic Government Publications at Central University Libraries, Southern Methodist University, http://digitalcollections.smu.edu/cdm/ref /collection/hgp/id/665.

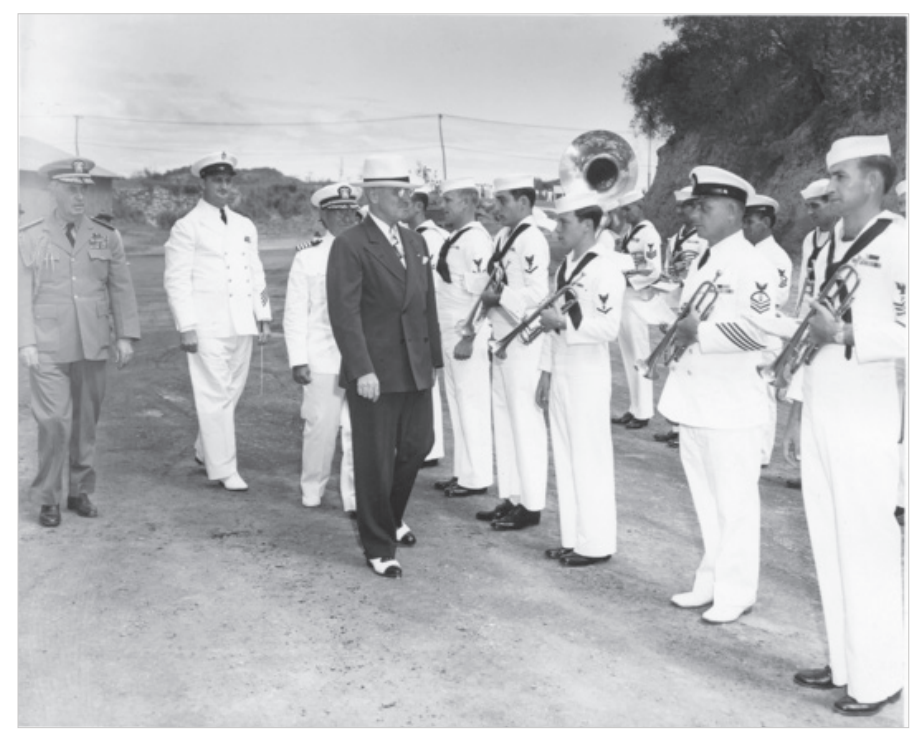

Figure 5. President Truman inspecting troops at Guantanamo Bay, 1948. Source: Photo from Harry Truman Library located by search on National Archives website, www.trumanlibrary.org/photographs/printRecord .php?id=39268.

both sides of the funding issue, with some declaring military bands an institutional necessity, and others criticizing them as a frivolous and unnecessary expense. Access to government published information will be important for both parties, as will news regarding future reports and policies.

Daniel E. Ray (danray@uw.edu), MLIS Candidate 2017, University of Washington.

\section{References}

1. B. P. Gleason, "Military Music in the United States: A Historical Examination of Performance and Training," Music Educators Journal 101, no. 3 (March 2015): 37, http://dx.doi.org/10.1177/0027432114563718.

2. "Military Band," Oxford Music Online, 2016, www .oxfordmusiconline.com.offcampus.lib.washington.edu /subscriber/article/opr/t237/e6805.

3. W. J. Clinton, "Remarks on the 200th Anniversary of the United States Marine Corps Band," Weekly Compilation of Presidential Documents 34, no. 29 (1998): 1367, http:// offcampus.lib.washington.edu/login?url=http://search .ebscohost.com/login. aspx?direct $=$ true $\& \mathrm{db}=\mathrm{mth} \& \mathrm{AN}=9$ 52936\& site $=$ ehost-live.

4. "Our Mission," US Army Music, accessed January 6, 2017, www.music.army.mil.

5. US Army Element School of Music, "A History of U.S. Army Bands," 2015, 13, https://fas.org/irp/doddir/army /armybands.pdf.

6. "Make Your Passion Your Profession," US Army Music, accessed January 6, 2017, www.music.army.mil/careers.

7. Clinton, "Remarks on the 200th Anniversary of the United States Marine Corps Band," 1367.

8. P. K. Freer, "Music Education and the MilitaryThe Special Focus Issue," Music Educators Journal, 101, no. 3 (March 2015): 34, https://dx.doi.org /10.1177/0027432114567838.

9. Gleason, "Military Music in the United States," 43.

10. "Make Your Passion Your Profession”; "Musician," Navy Recruiting Command, accessed January 6, 2017, www .navy.com/careers/arts-media/musician-jobs.html\#ft -work-environment; "The United States Coast Guard Band," United States Coast Guard, accessed January 6, 2017, www.uscg.mil/band/; United States Air Force Bands homepage, accessed January 6, 2017, www.bands.af.mil /bands; "Musician Enlistment Option Program," US Marine Corps, accessed January 6, 2017, www.marines .com/eligibility/musician-enlistment-option-program.

11. H.R. Rep. 112-705, "National Defence Authorization Act for Fiscal Year 2013," 2012, https://www.con gress.gov/congressional-report/112th-congress/house -report/705/1.

12. Walter Pincus, "House Votes to Cut Spending for Military Bands," Washington Post, July 7, 2011, https://www .washingtonpost.com/local/dc-politics/house-votes-to -cut-spending-for-military-bands/2011/07/07/gIQAx TyY2H_story.html. 
13. Betty McCollum, "Congresswoman McCollum's Remarks on the Amendment to Spending on Military Bands and the Deficit," 2012, https://mccollum.house .gov/congresswoman-mccollums-remarks-amendment -reduce-spending-military-bands-and-deficit.

14. 157 Cong. Rec. H4624 "Amendment No. 31 Offered by Mr. Carter," (daily ed., July 6, 2011), http://congressional .proquest.com/congressional/docview/t17.d18.cr06jy 2011_dat-89?accountid=146401.

15. H.R. Rep. 114-573, "National Defence Authorization Act for Fiscal Year 2017," 2016, https://www.congress .gov/114/crpt/hrpt537/CRPT-114hrpt537.pdf.

16. US Government Accountability Office, "Expenditures for Public Affairs Activities," B-161939, 1973, http:// www.gao.gov/assets/210/203336.pdf.

17. US Government Accountability Office, "Staffing, Funding, and Use of Military Bands," FPCD-81-72, 1981, http://www.gao.gov/products/FPCD-81-72.

18. National Defense Authorization Act for Fiscal Year 2016, H.R. 1735, 114th Cong. (2015), https://www.gov info.gov/content/pkg/BILLS-114hr1735rh/pdf/BILLS -114hr1735rh.pdf.

19. National Defense Authorization Act for FY91, Pub. L. No. 101-510 (1990), http://congressional.proquest.com :80/congressional/docview/t41.d42.101_pl_510?accountid $=14784$.
20. National Defense Authorization Act for FY10, Pub. L. No. 111-84 (2009), https://www.govinfo.gov/app/con tent/pkg/PLAW-111publ84/pdf/PLAW-111publ84.pdf.

21. Military Musical Units and Musicians: Performance Policies; Restriction on Performance in Competition with Local Civilian Musicians, 10 USC $\$ 974$ (2013), http:// uscode.house.gov/view.xhtml?path=/prelim@title10 /subtitleA/part2/chapter49\&edition=prelim.

22. US Department of the Army, "DoD Base Realignment and Closure 2005 Commission: Fiscal Year 2008/2009 Budget Estimates," 2007, http://asafm.army.mil/Documents /OfficeDocuments/Budget/BudgetMaterials/fy08-09 /milcon/brac2005.pdf.

23. A. Layton, personal communication with author, June 3, 2016.

24. National Defense Authorization Act for FY91, Pub. L. No. 101-510 (1990), http://congressional.proquest.com :80/congressional/docview/t41.d42.101_pl_510?accountid $=14784$.

25. "United States Code," Office of the Law Revision Council, US House of Representatives, accessed January 7, 2017, http://uscode.house.gov/browse.xhtml.

26. Military Musical Units and Musicians. 